\title{
THE ROLE OF STUDENT PERCEIVED OF LECTURER'S MEANING SUPPORT IN LEARNING ON STUDENT ENGAGEMENT
}

\author{
Linda Primana ${ }^{1}$, Shahnaz Safitri ${ }^{2}$, Pratiwi Widyasari ${ }^{1}$ and Friska Desintia ${ }^{2}$ \\ 'Departement of Educational Psychology, Universitas Indonesia \\ ${ }^{2}$ Student of Postgraduate Program in Psychology, Universitas Indonesia
}

\begin{abstract}
Previous researches have long been ascertained that intrinsic motivation and self-efficacy play an important role on student engagement. The purpose of present research is to identify whether student perceived of lecturer's meaning support in learning along with intrinsic motivation, and self-efficacy are meaningful predictors of student engagement. Variable of meaning support in learning is developed based on Self Determination Theory. 251 freshmen of social studies from Universitas Indonesia have participated in the research. In order to collect data, "School Engagement Measurement", "Meaning Support in Learning", "Learning Motivation", and "Self-efficacy, Stress, and Academic Success in College" scales have been employed. A Multiple Regression analysis has been used to predict the student's engagement based on student perceived of lecturer's meaning support in learning, the level of students' motivation and level of student's self-efficacy. It is found that student perceived of lecturer's meaning support in learning have predicted $14 \%$ of student engagement. This research indicates that lecturer's meaning support in learning also plays an important role on student engagement. The implications of the result are discussed.
\end{abstract}

Keywords: student perceived of lecturer's meaning support in learning, self-efficacy, student engagement, self-determination theory

\section{INTRODUCTION}

The transition period from high school to higher education considered as a difficult or challenging time for students. This condition makes them anxious as in higher education they were encouraged to be able to think and intellectually independent (Innis, James \& McNaught, 1995; Paulynice, 2013). Learning experiences in college that are far different from previous learning environment in high school often make students become confused, awkward, even stress in doing the process of learning in college (Depdiknas Dirjen Dikti, 2003; Paulynice, 2013). In higher education, the students' learning needs may change as their learning experience developing related to their interests, goals, and the fulfillment of their actualization in academic abilities. Interests, objectives, and the need for self-actualization would affect students' learning motivation.
Basically, learning activities and experiences in college are happened not only in the classroom. The number of extracurricular activities on campus, which may not exist before in high school, also made the students tempted to follow the activities that interest them. Students' attendance and assignments completions are often disturbed by non-academic activities. In fact, in order to be successful and graduate on time with good grades, students need to control themselves and focus on academic activities. Student engagement in learning activities affect not only to their academic success, but also to their optimal development, psychological wellbeing, and also prevent them from dropping outs (Carini, Kuh, \& Klein, 2006; Ferguson, Kasser , \& Jahng, 2010; Kuh, Cruce, Shoup, and Kinzie, 2008). 
Universitas Indonesia students which are selected through various methods of enrollment, consist of students with diverse characteristics. These enrollment methods are based on academic ability instead of ethnicity, religion, race, specific groups, gender, social status, or politics (Pedoman Penjaminan Mutu Akademik Universitas Indonesia, 2007). Thus, the Universitas Indonesia students that were selected by their grades in academic ability tend to have a different learning habit, motivation, experience, and life background. The diversity of student characteristics is a challenge for lecturers to teach students in learning activities. Lecturers are expected to help students develop their potentials towards their psychological well-being (Ferguson, Kasser, \& Jahng, 2010).

In their first semester, Universitas Indonesia students are required to take university compulsory course called Integrated Personality Development Skills (MPKT) for 6 credits. Through this course, students are trained to think critically, work in groups (collaborative learning [CL]), learn through electronic media, and learn from problem-based perspective (problem-based learning, [PBL]). These huge credits of MPKT course indirectly encourage students to be diligent and actively involved in the classroom activity in order to obtain good grades. Students are expected to be intrinsically motivated because the responsibility for their success is in themselves. Students need to create meaningful learning experiences and have confidence that they can motivate themselves intrinsically and engage in learning activities in the classroom. This study aimed to identify the role of students' perceived of lecturer meaning support toward learning engagement.

\section{LITERATURE REVIEW}

Student engagement is very essential for student success. Learning environment plays an important role toward student engagement (Christenson, Reschly, \& Wylie, 2012). In higher education, learning engagement has an important impact not only toward student success, but also influence student optimal development and their psychological wellbeing. In addition, student engagement could prevent drop outs (Carini, Kuh, \& Klein, 2006; Ferguson, Kasser, \& Jahng, 2010; Kuh, Cruce, Shoup, \& Kinzie, 2008). Student engagement is often conceptualized as a multidimensional construct (Appleton, Christenson, \& Furlong, 2008; Fredricks, Blumenfeld, \& Paris., 2004). However, there are some disagreements across the different conceptualizations in relation to the number of dimensions of engagement. In the literature, three dimensions of student engagement are typically described: cognitive, behavioral, and emotional engagement. In measuring student engagement in this study, researchers used understanding of student engagement based on a three dimensions typology. Cognitive involvement refers to thinking strategies used by students (Walker, Greene, \& Mansell, 2006). Behavioral engagement refers to student participation in learning (Birch \& Ladd, 1997). Emotional engagement refers to feelings or emotions of students in learning (Connell \& Wellborn, 1991).

Student engagement is a process of interaction and a dialectical relationship between intrapersonal factors and learning environment (Schunk \& Mullen, in Christenson, Reschly, \& Wylie, 2012). How students perceived their learning experience will affect their learning engagement. The role of the lecturer in the classroom activities is very important toward student engagement (Kuh, et al., 2008). Lecturers need to understand how students can be motivated to perform its activities in order to construct their knowledge. To provide learning experience that could encourage student engagement, student needs to fulfill their basic psychological needs, so they would intrinsically motivate to learn (Deci \& Ryan, 2000).

Learning engagement amongst students is varied. Students with low learning engagement level seemed less interested participating in classroom and their involvement just for attending the class only and not involve in classroom activities. Low learning engagement will not give a satisfactory learning outcome considering learning activities only to receive, repeat, and remember materials being taught. In this case, learning only occurs on the surface (Tagg, 2003). Students with low learning engagement develop their ability less in applying their knowledge in a more complicated situation (Haste, 2001, in Christenson, Reschly, \& Wylie, 2012).

Students with high learning engagement will deploy all its ability and their commitment to learning process. They perceived learning as something 
meaningful and in accordance with the purpose of their life. Learning engagement is not driven by the demands that come from their external self, but the curiosity arising from themselves (Haste, 2001, in Christenson Reschly, \& Wylie, 2012). High engaging in learning lead the students to a deeper comprehension and understanding of the subject matters. Deep understanding level in learning is important because due to learning approach oriented in understanding the depth of the material, the students will get good value and he can apply his knowledge in a different context or perspective. Deeper of understanding in learning will also make students enjoy their learning experience better (Tagg, 2003).

In order to be fully engaged in learning process, students need encouragement or motivation to perform his duties. Learning engagement is an indicator whether students get motivated or not, so that they would be involved in learning and in turn will contribute to their learning outcome and self development. Conversely, learning disengagement lead to a negative impact because it makes students passive and rely on external forces to control their learning (Trowler \& Trowler, 2010). Thus, the motivation that comes from inside, or often referred as intrinsic motivation, plays an important role in learning engagement. According to Self Determination Theory (SDT, Deci \& Ryan, 2000), learners can be intrinsically motivated when learners basic psychological needs - autonomy, competence, relatedness - are satisfied. SDT has been widely used to investigate the learning engagement and has been successfully applied in teaching (Jang, 2008; Reeve, et al., 2004; 2006).

SDT states that all students, aside from their age, gender, socioeconomic status, nationality, and cultural background, have an innate tendency to evolve and this condition can be a driving force for their learning engagement and success (Reeve, 2012 in Christenson, Reschly, \& Wylie, 2012). When other theory of motivation explaining how the expectations of learners, beliefs, and goals influence their engagement of learning, SDT is uniquely emphasized the role of teachers in encouraging learners' motivation as an essential point to facilitate the excellence learning engagement (Reeve, 2012 in Christenson, Reschly, \& Wylie, 2012).
Based on Deci and Ryan (2000), there are three universal basic psychological needs, namely the need for autonomy, the need for competence, and the need for relatedness. When these needs are met, motivation and well-being of a person will increase. On the contrary, when those needs are limited or obstructed, there will be a negative impact on the wellbeing/ satisfaction of one's life. Deci and Ryan (2000) stated that when students met these three basic psychological needs in the process of learning, intrinsic motivation is formed and they will enjoy their learning activities. On the other hand, if teachers tend to control students' behavior, intrinsic motivation will not appear and learning engagement tends to be low. In this case, learning activities determined by the teachers thus make the students didn't have freedom to express their ideas and feelings in the process of learning (Deci \& Ryan, 2000). Therefore, students possess inner motivational resources that learning environments can support or inhibit. However, this Basic Psychological Needs Theory postulate is not widely applicable in nonWestern societies, specifically needs for autonomy. The results showed inconsistency in otonomy needs among different culture (d'Ailly, 2003, 2004; Flowerday \& Schrow, 2003; Iyengar \& Lepper, 1999; Okazaki, 2011; Ratelle, Guay, Vallerand, La Rose, \& Senecal, 2007; Tonks, 2006). Therefore, culturally, there is the difference between how environment affect students' learning that positively perceived by students as supporting their autonomy and the learning environment that they perceived as controlling and yet can make them succeed.

As mention above, the needs for autonomy inconsistently would applicable in non-Western societies. Study involving non-Western participants found that self-esteem and spiritual needs are among the human primary needs (Grouzet, Kasser, Ahuvia, Dols, Kim, Lau, Ryan, Saunders, Schmuck, \& Sheldon, 2005; Sheldon, Elliot, Kim, \& Kasser, 2001). A study of the most satisfying needs based on research findings by Grouzet, et al. (2005) and Sheldon, Elliot, Kim, \& Kasser (2001) with the respondents of freshmen year social studies students in Universitas Indonesia (Primana, 2015, unpublished dissertation) revealed that SDT postulates of the need for autonomy, relatedness, and competence are the basic psychological needs perceived as important and primary on the top of three ranked by participant. 
However, not only the three basic psychological needs by SDT, four other needs as follows, the need for self-actualization, spiritual/meaning needs, pleasure stimulation, and self-esteem were also important to the respondents. In other words, from the students learning experience, they think of experiences in which they felt strongly related to others, autonomous, self-actualized, spiritual/ meaningful, pleasure, self-respected, and competent, in order to engage in learning. Therefore the seven basic psychological needs - the need for autonomy, relatedness, competence, self-actualization, spiritual needs, pleasure stimulation, and self-esteem emerged to be the most salient needs to be fulfilled to make students engage, motivated, autonomous, curious, proactive, enthusiast, and feel that learning is meaningful for their life. The meaning/spiritual needs occurred as an exclusively component amongst the entire needs. The present study aimed to seek the contribution of student's perceived of lecturer meaning support, along with intrinsic motivation and self-efficacy which have been strongly proved by previous studies (e.g. Bandura, 1997; Skinner \& Belmont, 1993) to be the salient factors that influence student engagement in learning.

\section{THE OBJECTIVES OF THE STUDY}

1. To examine the level of student engagement in learning.

2. To examine to what extend students' perceived of lecturer meaning support in learning.

3. To examine the contribution of students' perceived of lecturer meaning support in learning on student engagement.

\section{METHOD}

This research is a field research and respondents are selected based on convenience sampling techniques. A self-report questionnaire was used to gather information related to the objectives of the study. The samples are social studies freshmen from Universitas Indonesia. 251 students (female $=70.52 \%$ ) were asked to complete the questionnaires. In collecting research data, researchers assisted by a group of instructors. The instructors handed out questionnaires and give instructions to the respondents in the classroom. The token was given after the respondents completed the questionnaires.

In this study, student engagement in learning variable were assessed using School Engagement Measurement (SEM) scale by McArthur which has been developed by Blumenfeld and Fredricks (2005, in Fredricks, Blumenfeld, Friedel, \& Paris, 2005). Students' perceived of lecturer meaning support in learning was assessed by The Meaning Learning Scale developed by Primana (2015, unpublished dissertation) and constructed based on The Learning Climate Questionnaire Scale (Williams \& Deci, 1996). The Meaning Learning Scale consists of seven basic psychological needs - need for autonomy, competence, relatedness, meaning/spiritual needs, self-esteem, self-actualization, and pleasure stimulation needs. To assess intrinsic motivation, Learning Motivation Scale by Maulana, Opdenakker, den Brok, \& Bosker, (2011) was adapted. The respondents are asked to indicate their degree of agreement with the statements, scored on a five-point Likert-type scale (1=strongly disagree; 5=strongly agree). Self-efficacy, Stress, and Academic Success in College Scale (Zajacova, Lynch, \& Espenshade, 2005) was used to identify the students' self-efficacy. To fill in this self-efficacy scale, the respondents were asked to indicate their degree of their selfefficacy to the statements provided, and scored on a 10 range scale $(1=$ strongly unsure; $10=$ strongly confident). A descriptive statistics was used to identify the level of the student engagement in learning, coefficient correlation was used to analyze the relationships between variables, and multiple regression analysis was used to predict the contribution of students' perceived of lecturer meaning support in learning toward student engagement.

\section{RESULTS}

Table 1 displays the respondents' level of student engagement. The data shows that most of the respondents have a moderately high learning engagement with a percentage of $66 \%$ ranging from $2.5-3.49$, while $33 \%$ of respondents have high learning engagement ranging from $3.50-4.00$. The remaining $1 \%$ has moderately low learning engagement ranging from $1.50-2.49$. None of the 
respondents are in the low level category of learning

engagement.

Table 1 Level of Student Engagement

\begin{tabular}{lll}
\hline $\begin{array}{l}\text { Levels of Student } \\
\text { Engagement }\end{array}$ & Frequency & Percent $(\%)$ \\
\hline Low $(<1.49)$ & - & - \\
\hline $\begin{array}{l}\text { Moderately low } \\
(1.50-2.49)\end{array}$ & 3 & 1 \\
\hline $\begin{array}{l}\text { Moderately high } \\
(2.50-3.49)\end{array}$ & 165 & 66 \\
\hline High $(>3.50)$ & 83 & 33 \\
\hline
\end{tabular}

Mean $=3.38 ;$ Minimum $=1 ;$ Maximum $=5 ;$ Std. Deviation $=0.35$

Table 2 presents correlation between students' perceived of lecturer meaning support in learning, intrinsic motivation, self-efficacy on student engagement. As we see from the table, correlation between students' perceived of lecturer meaning support in learning and student engagement $(r=0.43$, $\mathrm{p}=0.000$ ) was quite strong and almost reach the correlation between self-efficacy and student engagement $(r=0.59, p=0.000)$. The correlation between students' perceived of lecturer meaning support in learning and student engagement $(r=0.43$, $\mathrm{p}=0.000$ ) was even slightly stronger than the correlation between intrinsic motivation and student engagement $(r=0.35, p=0.000)$.

Table 2 Correlation Matrix between Students' Perceived of Lecturer Meaning Support in Learning, Intrisic Motivation, and Self-Efficacy on Student Engagement

\begin{tabular}{|c|c|c|c|c|}
\hline & 1 & 2 & 3 & 4 \\
\hline Student engagement & 1.00 & & & \\
\hline $\begin{array}{l}\text { Students' perceived of } \\
\text { lecturer meaning } \\
\text { support in learning }\end{array}$ & $0.43 * *$ & 1.00 & & \\
\hline Intrinsic motivation & $0.35 * *$ & $0.20 *$ & 1.00 & \\
\hline Self-efficacy & $0.59 * *$ & $0.33^{* *}$ & $0.32 * *$ & 1.00 \\
\hline
\end{tabular}

** correlation is significant at the 0.01 level (2-tailed)

From Table 3 and Table 4 it can be seen that the multiple regression model with all three predictors produced $\mathrm{R}^{2}=.416, \mathrm{~F}=56.303, \mathrm{p}<.001$. Student's engagement can be explained by three predictors which are lecturer's meaning support in learning, intrinsic motivation, and self-efficacy. Those three variables contribute $42 \%$ to the variance of learning engagement and $14 \%$ was predicted by lecturer's meaning support in learning respectively.

Table 3 Estimation of Standard Error Deviation Model Summary

\begin{tabular}{|c|c|c|c|c|c|}
\hline Model & $\mathrm{R}$ & $\begin{array}{l}\mathrm{R} \\
\text { Square }\end{array}$ & $\begin{array}{l}\text { Adjust } \\
\text { ed R } \\
\text { Square }\end{array}$ & $\begin{array}{l}\text { Std. Error of the } \\
\text { Estimate }\end{array}$ & $\begin{array}{l}\text { R Square } \\
\text { Change }\end{array}$ \\
\hline
\end{tabular}

\begin{tabular}{llllll}
\hline 1 & $.373 \mathrm{a}$ & .139 & .135 & .819 & .139 \\
\hline 2 & $.473 \mathrm{~b}$ & .223 & .217 & .779 & .084 \\
\hline 3 & $.645 \mathrm{c}$ & .416 & .409 & .677 & .193 \\
\hline
\end{tabular}

a. Predictors: (Constant), Students' Perceived of Lecturer Meaning Support in Learning

b. Predictors: (Constant), Students' Perceived of Lecturer Meaning Support in Learning, Intrinsic Motivation

c. Predictors: (Constant), Students' Perceived of Lecturer Meaning Support in Learning, Intrinsic Motivation, Self-efficacy 
Table 4 Variation Analysis of Research Variables

\begin{tabular}{|c|c|c|c|c|c|c|}
\hline Model & & $\begin{array}{l}\text { Sum of } \\
\text { Squares }\end{array}$ & Df & $\begin{array}{l}\text { Mean } \\
\text { Square }\end{array}$ & $\mathrm{F}$ & Sig. \\
\hline & Regression & 25.882 & 1 & 25.882 & 38.557 & $.000^{\mathrm{b}}$ \\
\hline \multirow[t]{3}{*}{1} & Residual & 160.433 & 239 & .671 & & \\
\hline & Total & 186.314 & 240 & & & \\
\hline & Regression & 41.602 & 2 & 20.801 & 34.210 & $.000^{\mathrm{c}}$ \\
\hline \multirow[t]{3}{*}{2} & Residual & 144.713 & 238 & .608 & & \\
\hline & Total & 186.314 & 240 & & & \\
\hline & Regression & 77.530 & 3 & 25.843 & 56.303 & $.000^{d}$ \\
\hline \multirow[t]{2}{*}{3} & Residual & 108.784 & 237 & .459 & & \\
\hline & Total & 186.314 & 240 & & & \\
\hline
\end{tabular}
a. Dependent variable: Student Engagement
b. Predictors: (Constant), Students' Perceived of Lecturer Meaning Support in Learning
c. Predictors: (Constant), Students' Perceived of Lecturer Meaning Support in Learning, Intrinsic Motivation
d. Predictors: (Constant), Students' Perceived of Lecturer Meaning Support in Learning, Intrinsic Motivation, Self- efficacy

\section{CONCLUSION AND DISCUSSIONS}

This study intends to examine the relationship between students' perceived of lecturer's meaning support in learning on student engagement. From the data presented above, we can draw the following conclusion: three of the student engagement indicators, namely students' perceived of lecturer's meaning support in learning, intrinsic motivation, and self-efficacy are significant predictors for student engagement as the dependent variable. Descriptive analysis showed that most freshmen of social studies from Universitas Indonesia have quite high learning engagement and students' perceived of lecturer's meaning in learning as well. The fact that correlation between lecturer's meaning support in learning and student engagement was quite high showed that the students' need for meaning making in learning was salient for their learning activities. The more lecturer support the students' needs for meaning in learning, the more the students engage in learning.

Multiple regression analysis revealed that the most powerful correlation and contribution occurred between self-efficacy and student engagement, as previous researches ascertained (Bandura, 1997; Deci \& Ryan, 2000; Zimmerman, \& Cleary, 2006).
Important findings found in the correlation and contribution of students' perceived of lecturer's meaning support in learning and student engagement. The seven basic psychological needs namely needs for autonomy, needs of competence, need for relatedness, self-actualization needs, spiritual/ meaning needs, self-esteem, and pleasure stimulation, which was constructed based on SDT (Deci \& Ryan, 2000), are students' needs should be fulfilled in order to get students engage in their learning activities.

From this study, specifically for freshmen of social studies from Universitas Indonesia, the need for autonomy is not enough to drive them to be motivated intrinsically in the learning activities. On top of the SDT three basic psychological needs (Deci \& Ryan, 2000), the need of meaning making in learning along with intrinsic motivation and selfefficacy determined their engagement in learning.

Although there is much work remains to be done, this present study generates important findings in the student engagement research. In other words, there were some limitations of this study. The primary limitation of the present study was that lecturer meaning support variable that consists of seven basic psychological needs need to be tested through 
factorial analysis. Therefore, the concept of lecturer meaning support in learning would be clearer. In addition, because only freshmen of social studies in Universitas Indonesia were used in the study, the applicability of these findings to the larger populations remains untested.

\section{ACKNOWLEDGEMENTS}

This research received fund from grant for The Indexed International Publication for Students' Thesis year 2016 at the Universitas Indonesia (Hibah Publikasi Internasional Terindeks Untuk Tugas Akhir Mahasiswa UI Tahun 2016).

\section{REFERENCES}

Appleton, J. J, Christenson, S. L., \& Furlong, M.J. (2008). Student engagement with school: Critical conceptual and methodological issues of the construct. Psychology in the Schools, 45, 369-386.

Bandura, A. (1997). Self efficacy: The exercise of control. New York: W.H. Freeman.

Birch, S., \& Ladd, G. (1997). The teacher-child relationship and children's early school adjustment. Journal of School Psychology, 35, 61-79.

Carini, R.M., Kuh, G.D., \& Klein, S.P. (2006). Student Engagement and Student Learning: Testing the Linkages. Research in Higher Education, 47(1), 1-32.

Christenson, S. L., Reschly, A. L., \& Wylie, C. (2012). Handbook of Research on Student Engagement.Springer Science. DOI 10.1007/978-14614-2018-7_19.

Connell, J.P., \& Wellborn, J.G. (1991). Competence, autonomy, and relatedness: A motivational analysis of self-system processes. In Gunnar, M.R., \& Sroufe, L. A., (Ed). Self processes and development. The Minnesota symposia on child psychology, 23, 43-77. New Jersey: Lawrence Erlbaum Associates, Inc.

d'Ailly, H. (2003). Children's autonomy and perceived control in learning: A model of motivation and achievement in Taiwan. Journal of Educational Psychology, 95(1), 84-96. DOI: 10.1037/00220663.95.1.84.

d'Ailly, H. (2004). The role of choice in children's learning: A distinctive cultural and gender difference in efficacy, interest, and effort. Canadian Journal of Behavioural Science/Revue, 36(1), 17-29. DOI: 10.1037/h0087212

Deci, E. L., \& Ryan, R. M. (2000). The "what" and "why" of goal pursuits: Human needs and the selfdetermination of behavior. Psychological Inquiry, 11, 227-268.
Departemen Pendidikan Nasional Direktorat Jenderal Pendidikan Tinggi (Depdiknas Dirjen Dikti) (2003). Panduan umum pengenalan kehidupan kampus bagi mahasiswa baru. Jakarta: Direktorat Pembinaan Akademik dan Kemahasiswaan.

Ferguson, Y.L., Kasser, T., \& Jahng, S. (2010). Differences in life satisfaction and school satisfaction among adolescents from three nations: The role of perceived autonomy support. Journal of Research on Adolescence, 21(3),

Flowerday, T., \& Schraw, G. (2003). Effect of choice on cognitive and affective engagement. The Journal of Educational Research, 96(4), 207-215. DOI: 10.1080/00220670309598810

Fredricks, J.A., Blumenfeld, P.C., \& Paris, A.H. (2004). School engagement: Potential of the concept, state of the evidence. Review of Educational Research, 74(1), 59-109. DOI: 10.3102/00346543074001059

Fredricks, J. A., Blumenfeld, P. C., Friedel, J., \& Paris, A. (2005). School engagement. In K. A. Moore \& L. Lippman (Eds.), Conceptualizing and measuring indicators of positive development: What do children need to flourish? New York: Kluwer Academic/Plenum Press.

Grouzet, F. M. E., Vallerand, R. J., Thill, E. E., \& Provencher, P. (2004). From environmental factors to outcomes: A test of an integrated motivational sequence. Motivation and Emotion, 28, 331-346.

Innis, C., James, R., \& McNaught, C. (1995). First year on the campus: Diversity in the initial experiences of Australian undergraduates. Canberra: Australian Government Publishing Service.

Iyengar, S.S., \& Lepper, M.R. (1999). Rethinking the value of choice: A cultural perspective on intrinsic motivation. Journal of Personality and Social Psychology, 76(3), 349-366. DOI: 10.1037/00223514.76.3.349

Jang, H. (2008). Supporting students' motivation, engagement, and learning during an uninteresting activity. Journal of Educational Psychology, 100, 798-811.

Kuh, G.D., Cruce, Ty. M., Shoup, R., Kinzie, J. (2008). Unmasking the effects of student engagement on first-year college grades and persistence. The Journal of Higher Education, 79(5), 540-563. DOI: 10.1353/jhe.0.0019

Kuh, G. D., Kinzie, J., Buckley, J., Bridges, B., \& Hayek, J. C. (2007). Piecing together the student success puzzle: Research, propositions, and recommendations. ASHE Higher Education Report, 32(5). San Francisco: Jossey-Bass.

Kuh, G.D., Cruce, Ty. M., Shoup, R., Kinzie, J. (2008). Unmasking the effects of student engagement on first-year college grades and persistence. The 
Journal of Higher Education, 79(5), 540-563. DOI: 10.1353/jhe.0.0019

Maulana, R., Opdenakker, M., den Brok, P., \& Bosker, R. (2011). Teacher-student interpersonal relationships in Indonesia: Profiles and importance to student motivation. Asia Pacific Journal of Education, $\quad 31(1), \quad 33-49 . \quad$ DOI: 10.1080/02188791.2011.544061.

Okazaki, M. (2011). An investigation into the relationship between learner autonomy support and student motivation in the Japanese university setting. Unpublished Dissertation: The University of Birmingham

Paulynice, R. (2013, Nov,26). What causes many college students to fail or drop out (supplemental material). Hubpages Retrieved from paulyniceroldes.hubpages.com/hub/What-Causes-

College-Students-to-Fail-or-Dropout.

Pedoman Penjaminan Mutu Akademik Universitas Indonesia. (2007). Depok: UI Press.

Primana, L. (2015). The contribution of lecturer's meaning support, intrinsic motivation, self-efficacy, and student's perceived epistemic authority, on learning engagement of universitas indonesia's students. Dissertation: unpublished.

Ratelle, C.F., Guay, F., Vallerand, R.J., Larose, S., \& Senecal, C. (2007). Autonomous, controlled, and amotivated types of academic motivation: A personoriented analysis. Journal of Educational Psychology, 99(4), 734-746. DOI: 10.1037/0022-0663.99.4.734.

Reeve, J. , Jang, H., Carrell, D., Jeon, S., \& Barch, J. (2004). Enhancing students' engagement by increasing teachers' autonomy support. Motivation and Emotion, 28, 147-169.

Reeve, J. (2006). Teachers as facilitators: What autonomy-supportive teachers do and why their students benefit. The Elementary School Journal, 106(3), 225-236.
Sheldon, K.M., Elliot, A.J., Kim, Y., \& Kasser, T. (2001). What is satisfying about satisfying events? Testing 10 candidate psychological needs. Journal of Personality and Social Psychology, 80(2), 325-339. DOI: 10.1037/0022-3514.80.2.325.

Skinner, E. A., \& Belmont, M. J. (1993). Motivation in the calssroom: Reciprocal effects of teacher behavior and student engagement across the school year. Journal of Educational Psychology, 85(4), 572.

Tagg, J. (2003). The learning paradigm college. Boston, MA: Anker.

Tonks, S.J.M. (2006). A Mixed-Methods Study of Perceived Academic Autonomy in Japanese Students and Its Relations to Their Motivation. Dissertation: University of Maryland.

Trowler, V. \& Trowler, P. (2010). Student engagement evidence summary. Department of Educational Research University Lancaster, Heslington, York: The Higher Education Academy

Walker, C., Greene, B. \& Mansell, R. (2006). Identification with academics, intrinsic/extrinsic motivation, and self-efficacy as predictors of cognitive engagement. Learning and Individual Differences, 16(1), 1-12.

Williams, G.C., \& Deci, E.L. (1996). Internalization of biopsychosocial values by medical students: A test of self-determination theory. Journal of Personality and Social Psychology, 70(4), 767-779. DOI: 10.1037/0022-3514.70.4.767.

Zajacova, A., Lynch, S.M., \& Espenshade, T.J. (2005). Self-efficacy, stress, and academic success in college. Research in Higher Education, 46(6), 677706. DOI: 10.1007/s11162-004-4139-z.

Zimmerman, B. J., \& Cleary, T. J. (2006). Adolescents' development of personal agency: The role of self-efficacy beliefs and self-regulatory skill. In F. Pajares \& T. Urdan (Eds). Self-efficacy beliefs of adolescence (hal. 45-69). Greenwich, CT; Information Age Publishing. 